\title{
DERADIKALISASI AGAMA DALAM PEMAHAMAN TEISS-TEKS LITERATUR PENDIDIKAN PESANTREN
}

\section{Rustam Ibrahim}

Universitas Nahdlatul Ulama Surakarta

rustam_ibrahim85@yahoo.co.id

The author's interest in researching on de-radicalization of religion in the literature of islamic boarding school education was driven by the fact that religion deradicalization are now starting to touch many aspects of society. Religious radicalism is often associated with terrorism, such as suicide bombers under the pretext of jihad (martyrdom), violence in the name of amar ma'ruf-nahy munkar (commanding the good and forbidding the evil), even now starting to organize religious radicalism in the establishment of the state. Ironically, some of the perpetrators of terrorism are graduates of boarding schools. This is due to the fact that there are several texts in the literature of boarding school education that are vulnerable to radical behaviors, such as jihad, commanding the good, or fighting against non-Muslims. It makes boarding schools are negatively affected despite the fact that they are institutions of Islamic education in Indonesia who spread the teachings of Islam which is rahmatan lil Alamin (blessing for the universe), tolerant, and contextual. Therefore, this study wanted to know about de-radicalization of religion in the understanding of texts in the literature of boarding school education, particularly related to the meaning of jihad, commanding the good, and Islam as the blessing for the universe.

This research uses library research, which is a pure literature research. This method is used for obtaining data on de-radicalization in the view of boarding schools using descriptive approach. This research is a study on religious teachings in relation to society, nature, character, and the influence of the thoughts and ideas in forming the character of a group.

De-radicalization of religion in the literature of boarding schools includes several things. First, boarding schools should not teach jihad with war, but with education. Next, the applications of amar ma'ruf-nahy munkar must be done through certain stages, so that the direction fits the condition of the object of the missionary endeavor. Violence must 
not be used as long as it is still possible to use subtle ways since violence is only legalized when the situation is extremely urgent.

Keywords: De-radicalisation of Religion, Text, Literature, Boarding School

\section{A. Pendahuluan}

Radikalisme agama saat ini mulai menyentuh berbagai aspek di masyarakat. Radikalisme agama sering diidentikkan dengan aksi terorisme, seperti melakukan bom bunuh diri dengan dalih jihad, melakukan kekerasan atas nama amar máruf nahi munkar, bahkan kini radikalisme agama mulai terorganisir dalam pendirian negara. Ironisnya mereka membungkus aksi radikal dengan menggunakan dalil-dalil Islam sebagai dasar pijakan aksi mereka. Para teroris melakukan aksi bom bunuh diri dengan mengatasnamakan jihad, menghalalkan perampokan dengan dalih harta fai', menganggap aparat pemerintah sebagai antek orang kafir, dan kejahatan-kejahatan lainnya yang mereka anggap sebagai kebenaran. Yang paling mengherankan, sebagian dari mereka adalah lulusan pesantren, apalagi dalam literatur pesantren terdapat beberapa teks yang rentan dengan perilaku radikal, seperti jihad, amar ma'ruf, atau memerangi non muslim. Hal tersebut menjadikan pesantren terkena dampak negatif. Terutama asumsi publik yang mengkaitkan ajaran teroris dengan ajaran pesantren. Akhirnya publik banyak yang bertanya-tanya: apakah pesantren menjadi sarang teroris?

Pada tahun 2005, Wakil Presiden RI Muhammad Jusuf Kalla hendak melakukan pengawasan teliti terhadap aktivitas pesantren yang tersebar di tanah air. Menurutnya, maraknya aksi teror seperti peristiwa bom Bali beberapa waktu lalu tidak menutup kemungkinan juga dilakukan oleh para santri dari pondok pesantren yang tersebar di tanah air. ${ }^{1}$

Mantan kepala BIN, Syamsir Siregar, juga pernah menyatakan bahwa perlu ada penetrasi ke dalam kelompok-kelompok Islam radikal untuk menceraiberaikan kekuatan mereka. Caranya? Dengan melakukan perpecahan internal. Ini, menurut Syamsir Siregar, adalah salah satu strategi BIN untuk memberantas terorisme. ${ }^{2}$ Kendati dalam pernyataannya Syamsir Siregar tidak menyebut nama pesantren, namun semua orang paham bahwa pesantren pasti tak luput dari sasaran penyusupan itu. Apalagi intel-intel polisi terbukti keluyuran di beberapa pesantren ${ }^{3}$.

Abu Rahmat juga menilai pendidikan dan lembaga pendidikan sangat berpeluang menjadi penyebar benih radikalisme dan sekaligus penangkal (baca: deradikalisasi) Islam radikal. Ia juga mengemukakan bahwa beberapa studi tentang radikalisme dan terorisme, mensinyalir adanya lembaga pendidikan Islam tertentu (terutama yang nonformal, seperti pesantren) ${ }^{4}$ telah mengajarkan fundamentalisme dan radikalisme kepada para peserta didik.

Muhammad Qosim juga menyetujui tentang kemungkinan adanya pesantren yang memiliki

1 Nurul Huda Ma’arif, "Pesantren (kembali) Dicurigai", AULA (Nopember 2005), hlm. 35-38.

2 Nurul Huda Ma’arif, "Pesantren (kembali) Dicurigai", AULA (Nopember 2005), hlm. 35-38.

3 Rivai Hutapea,"Pesantren : Yang Berjasa Yang Tersudutkan”, Sabili,online, http:// Sabili. co .id /telut-e 13 th X111 05. htm.2004,di akses 14 Mei 2006.

4 Abu Rahmat, Radikalisme Islam dan Upaya Deradikalisasi Paham Radikal, dalam Jurnal Walisongo, Volume 20 No. 1. Mei 2012. Hlm 80. 
tradisi radikal, terutama pesantren yang kehadirannya tanpa memiliki ikatan emosional dengan masyarakat sekitar. Ia dibangun untuk mengintrodusir suatu gagasan dan ideologi keislaman yang sudah dibentuk oleh para pengurusnya, sehingga ia tidak peka terhadap problema sosial masyarakat sekitar ${ }^{5}$.

Terlepas dari keterlibatan sebagian kecil civitas pesantren dengan aksi teror, pada dasarnya dunia pesantren secara umum tidak menghendaki tindakan yang mengarah pada radikalisasi ajaran agama, apalagi sampai menimbulkan kekerasan dan teror. Dunia pesantren lekat dengan kehidupan yang moderat dan toleran. Dunia pesantren sangat kental dengan nilai, pemikiran dan kehidupan yang sederhana, kejujuran, toleran (tasamuh), moderat, (tawasuth), seimbang dengan faham inklusifitas (infitahiyyah) dan pluralitas (ta'addudiyyah). Nilai-nilai tersebut menempatkan pesantren menjadi ummatan wasathan (ummat yang moderat). Nilai dan pemikiran tersebut akan sangat membantu dalam proses deradikalisasi agama dalam rangka penanggulangan terorisme ${ }^{6}$. Menurut Imam Mustofa, deradikalisasi agama adalah segala upaya yang digunakan untuk menetralisir pemahaman agama secara keras melalui pendekatan interdisipliner, politik, hukum, ekonomi, psikologi, agama dan sosial-budaya bagi mereka yang dipengaruhi atau terekspose paham radikal atau prokekerasan yang mengatasnamakan agama ${ }^{7}$.

Oleh karena itu, penulis tertarik untuk meneliti tentang bagaimana deradikalisasi agama dalam pemahaman teks literatur pendidikan pesantren, fokus penelitiannya adalah tentang pemaknaan jihad, amar ma'ruf nahi munkar dan Islam rahmatan lil alamin. Tujuannya adalah untuk mengetahui deradikalisasi agama dalam pendidikan pesantren tentang pemaknaan jihad, amar ma’ruf nahi munkar dan ajaran anti radikalisme. Penulis berusaha menelusuri terhadap literatur yang dipakai pesantren khususnya dalam masalah deradikalisasi agama. Literaturliteratur yang banyak digunakan antara lain: ${ }^{8}$ Kitab Fiqih mengacu pada Kitab Fiqh al-Islami karya Dr. Wahbah Zuhaili, Fathu al-Mu'in, dan Fathu al-Qorib. Kitab Tafsir mengacu pada Tafsir Jalalain karya Jalauddin al-Suyuthi dan Jalaluddin al-Mahalli, juga pada tafsir al-Qurtubi, Kitab akhlak/tasawuf mengacu pada kitab Ihya' Ulum ad-Dien Karya Imam Al-Ghazali, dan kitab Hadits mengacu pada kitab Bukhori Muslim.

\section{B. Review Pustaka}

Kajian tentang deradikalisasi agama beberapa kali telah dibahas dalam sebuah penelitian, Ahmad Syafii Maarif dalam tulisannya Masa Depan Islam di Indonesia (2009), ia menjelaskan bahwa radikalisme lahir dari ketidak berdayaan umat Islam dalam menghadapi modernitas, sehingga mencari dalil-dalil agama untuk menghibur diri dalam sebuah dunia yang mereka

5 Muhammad Qosim, Pesantren dan Wacana Radikalisme, Jurnal KARSA, Vol. IX No. 1 April 2006. Hlm 79.

6 Imam Mustofa, Pesantren dan Deradikalisasi Agama, http://mushthava.blogspot.com/2012/02/pesantrendan-deradikalisasi-agama.html. diunduh tanggal 11 Maret 2015.

7 Imam Mustofa, Deradikalisasi Ajaran Agama: Urgensi, Problem dan Solusinya, http://mushthava.blogspot. com/2012/02/pesantren-dan-deradikalisasi-agama.html. diunduh tanggal 11 Maret 2015.

8 Abudin Nata, Sejarah Pertumbuhan dan Perkembangan Lembaga- lembaga Pendidikan Islam di Indonesia, Jakarta : Grasindo, 2001, hlm 61. 
bayangkan belum tercemar. Tidak hanya berhenti di situ, mereka menyusun kekuatan politik untuk melawan modernitas melalui berbagai cara, karena itu wajar terjadi benturan dengan golongan muslim lain yang tidak setuju dengan cara mereka. Teori lain menjelaskan bahwa radikalisme di berbagai negara Muslim didorong oleh rasa kesetiakawanan terhadap nasib yang menimpa saudara-saudaranya di Palestina, Kashmir, Afghanistan, Syiria, dan Iraq. Rasa solider sebenarnya dimiliki oleh segenap umat Islam sedunia, hanya yang membedakan justru ditunjukkan oleh sikap sekelompok minoritas yang kebablasan dan di luar penalaran, misalnya dengan praktik bom bunuh diri dengan membunuh manusia lain di Indonesia yang relatif aman, Indonesia bukan Palestina, bukan Iraq, tetapi mengapa praktik biadab tersebut dilakukan di sini?

Muhammad Qosim (2006) pernah melakukan penelitian tentang Pesantren dan Wacana Radikalisme, ia menilai bahwa tradisi pemikiran dan sikap keberagamaan pesantren adalah tradisi yang terbuka, toleran, dan santun. Tradisi ini telah dibuktikan warga pesantren melalui perjalanan sejarahnya yang panjang dalam kehidupan bermasyarakat, bernegara, dan berbangsa. Ada beberapa faktor yang menyebabkan tradisi pesantren bercorak toleran; pertama, pesantren merupakan lembaga berbasis realitas sosial yang tumbuh dan berkembang bersama masyarakat. Kedua, paham keagamaan yang dianut kalangan pesantren adalah paham ahl al-sunnnah wa al-jamäah yang cenderung moderat. Ketiga, kitab-kitab rujukan yang dikaji di pesantren adalah kitab-kitab pilihan (al-kutub al-mu'tabārah) karya ulama klasik abad pertengahan yang cenderung moderat. Kendati demikian, tidak menutup kemungkinan adanya pesantren yang memiliki tradisi radikal, terutama pesantren yang kehadirannya tanpa memiliki ikatan emosional dengan masyarakat sekitar. Ia dibangun untuk mengintrodusir suatu gagasan dan ideologi keislaman yang sudah dibentuk oleh para pengurusnya, sehingga ia tidak peka terhadap problema sosial masyarakat sekitar?.

Abu Rahmat (2012) pernah melakukan penelitian tentang radikalisme di sekolah formal. Lembaga-lembaga pendidikan diduga tidak kebal terhadap pengaruh ideology radikal. Penelitian ini menyimpulkan bahwa: (1) Beberapa guru mengakui adanya konsep Islam radikal yang mungkin menyebar di kalangan siswa karena kurangnya pengetahuan keagamaan; (2) Unit-unit kajian Islam di sekolahsekolah berkembang baik namun tidak ada jaminan adanya kekebalan dari radikalisme karena proses belajarnya diserahkan kepada pihak ketiga; (3) Di dalam buku rujukan dan kertas kerja terdapat beberapa pernyataan yang dapat mendorong siswa untuk membenci agama atau bangsa lain. Dapat disimpulkan bahwa ada beberapa strategi deradikalisasi yang dapat diimplementasikan yaitu deradikalisasi preventif, deradikalisasi preservatif terhadap Islam moderat, dan deradikalisasi kuratif ${ }^{10}$.

Ahmad Darmadji (2011) menulis tentang pondok pesantren di Indonesia berkembang dalam kerangka yang relatif khas dan memiliki watak yang berbeda dengan pendidikan sejenis di negara lain mengingat sifat damai yang dirasakan saat Islam masuk ke tanah air. Hal ini

9 Muhammad Qosim, "Pesantren dan Wacana Radikalisme", Jurnal KARSA, Vol. IX No. 1 April 2006.

10 Abu Rokhmad, "Radikalisme Islam dan Upaya Deradikalisasi Paham Radikal", Jurnal Walisongo, Volume 20, Nomor 1, Mei 2012. 
membawa implikasi berupa watak keislaman yang damai di sebagian besar pondok pesantren yang ada termasuk kontribusi yang diberikan bagi bangsa dan negara. Bahwa kemudian terjadi radikalisasi pemahaman pad a pondok pesantren tertentu yang berdampak pada aksi terorisme di Indonesia selayaknya diletakkan dalam konteks perkembangan gerakan Islam transnasional akibat berbagai perkembangan dunia yang ada ${ }^{11}$.

Dari beberapa penelitian yang dilakukan, belum ada yang meneliti tentang deradikalisasi agama dalam pemahaman literatur pendidikan pesantren, khususnya terkait pemaknaan jihad, amar ma'ruf nahi munkar, dan Islam rahmatan lil alamin di pesantren.

\section{Kerangka Teori}

Abdul Muchith Muzadi menjelaskan bahwa pesantren memiliki pedoman "Al-Muhafazah 'ala al-qadim as-shalih wa al-akhdzu bi al-jadid al-ashlah" (memelihara tradisi lama yang baik dan mengambil tradisi baru yang lebih baik), bahwa hal-hal yang dapat diterima oleh Islam atau bermanfaat bagi Islam dan kehidupan, bukan saja boleh, malah perlu dicari, diambil, dan dikembangkan. Sedangkan hal yang tidak diperbolehkan adalah hal-hal dari luar yang bertentangan atau berbahaya bagi Islam $^{12}$.

Pedoman di atas dijabarkan Husein Muhammad dengan merumuskan pedoman sikap bermasyarakat aswaja, yaitu sikap Tawasuth (moderat), Tasamuh (toleran), Tawazun (serasi dan seimbang), I'tidal (adil dan tegas), dan Amar Ma'ruf Nahi Munkar (menyeru kepada kebajikan dan mencegah kemunkaran). Moderat (tawassut) adalah suatu sikap yang menengahi antara dua pikiran yang ektrem: antara Qadariyah (freewillisme) dan Jabariyah (fatalisme), ortodoks Salaf dan rasionalisme Mu'tazilah, dan antara sufisme falsafi dan sufisme salafi ${ }^{13}$.

Pedoman pertama, tawasuth, merupakan sebuah sikap tengah atau moderat yang tidak cenderung ke kanan atau ke kiri. Dalam konteks berbangsa dan bernegara dan dalam bidang lain, pemikiran moderat ini sangat urgen menjadi semangat dalam mengakomodir beragam kepentingan dan perselisihan, lalu berikhtiar mencari solusi yang paling $a s h l a h^{14}$.

Sikap tawasuth juga dibuktikan pesantren dalam memahami teks agama, al-Qur'an dan Hadit misalnya, dipahami secara kontekstual dan bukan tekstual. Teks agama dipahami secara membumi dan sesuai dengan situasi dan kondisi zaman. Pesantren menolak memahami teks agama secara rigid dan tekstual, melainkan sebuah pembacaan yang kontekstual dan membumi. Teks-teks agama direproduksi sesuai semangat zaman. Tidak salah jika pesantren tidak pernah menyerukan suara-suara perjuangan penerapan syari'at Islam. Sebab dalam pandangan pesantren, Pancasila dan UUD 1945 merupakan ideologi yang final dan tidak perlu diotak-atik lagi. Posisi syari'at Islam dalam pandangan pesantren berfungsi sebagai roh atau semangat yang menjiwai

11 Ahmad Darmadji, Pondok Pesantren dan Deradikalisasi Islam di Indonesia, Jurnal Millah Vol. XI, No 1, Agustus 2011.

12 Abdul Muhith Muzadi, NU dalam Perspektif Sejarah dan Ajaran, Surabaya: Khalista, hlm 73

13 Husein Muhammad, "Memahami Sejarah Ahlus Sunnah wal Jama'ah yang Toleran dan Anti Ekstrem" dalam Imam Baihaqi (ed.), Kontroversi Aswaja, Yogyakarta: LKiS, 2000, hlm 37.

14 Husein Muhammad, "Memahami Sejarah Ahlus Sunnah wal Jama'ah yang Toleran dan Anti Ekstrem" dalam Imam Baihaqi (ed.), Kontroversi Aswaja, Yogyakarta: LKiS, 2000, hlm 37. 
kehidupan berbangsa dan bernegara, bukan berfungsi sebagai hukum dalam negara itu sendiri ${ }^{15}$.

Kedua adalah sikap toleran (tasamuh) yang sangat besar terhadap pluralisme pikiran. Berbagai pikiran yang tumbuh dalam masyarakat muslim mendapatkan pengakuan yang apresiatif. Keterbukaan yang demikian lebar untuk menerima berbagai pendapat menjadikan Aswaja memiliki kemampuan untuk meredam berbagai konflik internal umat. Corak ini sangat tampak dalam wacana pemikiran hukum Islam. Sebuah wacana pemikiran keislaman yang paling realistik dan paling banyak menyentuh aspek relasi sosial ${ }^{16}$.

Dalam diskursus sosial-budaya, Aswaja banyak melakukan toleransi terhadap tradisi-tradisi yang telah berkembang di masyarakat, tanpa melibatkan diri dalam substansinya, bahkan tetap berusaha untuk mengarahkannya. Formalisme dalam aspek-aspek kebudayaan dalam Aswaja tidaklah memiliki signifikansi yang kuat. Karena itu tidak mengherankan dalam tradisi kaum Sunni terkesan wajah kultur Syiah atau bahkan juga Hinduisme. Inilah sebabnya mengapa Aswaja sering dikecam oleh kelompok Salafyyun, semenjak dari pengikut Ahmad bin Hanbal, Ibnu Taimiyah sampai Muhammad bin Abdul Wahhab, sebagai ahli khurafat, kaum bid'ah atau kelompok quburiyyun ${ }^{17}$.

Sikap toleran Aswaja yang demikian telah memberikan makna khusus dalam hubungannya dengan dimensi kemanusiaan secara lebih luas. Hal ini pula yang membuatnya menarik banyak kaum muslimin di berbagai wilayah dunia. Pluralistiknya pikiran dan sikap hidup masyarakat adalah keniscayaan. Dan ini akan mengantarkannya pada visi kehidupan dunia yang rahmat di bawah prinsip Ketuhanan Yang Maha Esa.

Ketiga, Aswaja selanjutnya berusaha mengembangkan keseimbangan atau tawazun, satu ciri lain dari Aswaja. Tawazun berarti keseimbangan, tidak berat sebelah, tidak berlebihan sesuatu unsur atau kekurangan unsur lain. Pola ini dibangun lebih banyak untuk persolanpersoalan yang berdimensi sosial politik. Dalam bahasa lain, melalui pola ini Aswaja ingin menciptakan integritas dan solidaritas sosial umat. Pola demikian, misalnya tampak pada sikap dan pandangan al-Ghazali. Melalui karyanya, Tahafut al-Falasifah, al-Ghazali dengan terangterangan menyerang kaum filosof yang dinilainya telah melakukan kesalahan dan penyimpangan. Pikiran-pikiran kaum filosof yang membicarakan persoalan-persoalan metafisika dianggap telah mengacaukan dan menyesatkan umat. al-Ghazali, melalui buku ini, berusaha menghentikan gelombang filsafat Hellenistik tersebut ${ }^{18}$.

Keempat adalah ta'adul, yang berarti tegak lurus, tidak condong ke kanan atau kiri. Kata ini diambil dari al-'adlu yang berarti keadilan atau ídilu atau bersikap adillah. Táadul berarti lurus, Allah sejak semula sudah meletakkan dalam Islam segala kebaikan, dan segala kebaikan

15 Suparman Syukur, "Islam Radikal VS Islam Rahmah Kasus Indonesia," dalam Teologia, Jurnal Ilmu-Ilmu Ushuluddin, Volume 23, Nomor 1, Januari 2012. Hlm 99.

16 Husein Muhammad, "Memahami Sejarah Ahlus Sunnah wal Jama'ah yang Toleran dan Anti Ekstrem" dalam Imam Baihaqi (ed.), Kontroversi Aswaja, Yogyakarta: LKiS, 2000, hlm 41.

17 Husein Muhammad, "Memahami Sejarah Ahlus Sunnah wal Jama'ah yang Toleran dan Anti Ekstrem" dalam Imam Baihaqi (ed.), Kontroversi Aswaja, Yogyakarta: LKiS, 2000, hlm 41.

18 Abdul Muhith Muzadi, NU dalam Perspektif Sejarah dan Ajaran, Surabaya: Khalista, hlm 70. 
itu pasti terdapat di antara dua ujung yakni tat\}arruf, sifat mengujung (ekstrem) dan liberal (taharrur). Prinsip dan karakter ta'adul yang sudah menjadi karakter Islam ini harus diterapkan dalam segala bidang agar sikap serta tingkah laku umat Islam selalu menjadi saksi dan pengukur kebenaran bagi semua sikap dan tingkah laku manusia pada umumnya ${ }^{19}$.

Nilai Aswaja pesantren sangat identik dengan pergulatan intelektualisme dan penghargaan terhadap kemajemukan pemikiran. Moderatisme mengkampanyekan dimensi kelenturan, kesantunan, dan keadaban Islam. Islam sebagai penebar kasih, cinta dan sayang (rahmatan lil 'alamin). Moderatisme amat bertentangan dengan pandangan keagamaan yang selalu berwajah sangar dan keras dari beberapa kelompok muslim ${ }^{20}$.

\section{Metode Penelitian}

Penelitian ini menggunakan metode library research, yaitu suatu riset kepustakaan atau penelitian kepustakaan murni. ${ }^{21}$ Metode ini untuk memperoleh data tentang deradikalisasi pesantren dengan menggunakan pendekatan deskriptif. Mengingat bahwa penelitian ini adalah penelitian pustaka, yaitu penelitian terhadap ajaran dalam hubungannya dengan masyarakat, sifat-sifat, watak, pengaruh pemikiran dan idenya serta membentuk watak kelompok, penelitian ini masuk dalam kategori penelitian pustaka. ${ }^{22}$

Penelitian ini juga bisa disebut studi naskah. Studi ini bertujuan untuk menyusun rekonstruksi teks secara obyektif dan sistematis dengan jalan mengumpulkan, mengevaluasi, memverifikasi serta mansintesiskan bukti-bukti untuk mengungkap fakta dan memperoleh kesimpulan yang kuat. ${ }^{23}$ Dan studi naskah selalu menggunakan dua sumber data, yaitu sumber data primer dan sumber data sekunder. Data primer adalah data authentik atau data langsung dari tangan pertama tentang masalah yang diungkapkan. Secara sederhana data ini disebut data asli. ${ }^{24}$ Sumber data primer yang dimaksud adalah kitab yang dijadikan kurikulum dalam pesantren. Data sekunder adalah data yang diperoleh atau dikutip dari sumber lain sehingga tidak bersifat authentik (tidak asli) karena diperoleh dari tangan kedua, ketiga dan seterusnya. ${ }^{25}$ Sumber data sekunder ini penulis gunakan sebagai data pelengkap atau analisa perbandingan untuk mengetahui otentitas pemikiran pesantren tentang jihad. Data tersebut harus dapat dipertanggung jawabkan validitasnya.

Teknik analisis data dalam penelitian ini bersifat deskriptif, yaitu usaha untuk menginterpretasikan mengenai apa yang ada tentang kondisi, pendapat yang sedang berlangsung serta akibat (efek) yang terjadi atau kecenderungan yang tengah berkembang. ${ }^{26}$ Metode ini

19 Abdul Muhith Muzadi, NU dalam Perspektif Sejarah dan Ajaran, Surabaya: Khalista, hlm 71.

20 Suparman Syukur, "Islam Radikal VS Islam Rahmah Kasus Indonesia," dalam Teologia, Jurnal Ilmu-Ilmu Ushuluddin, Volume 23, Nomor 1, Januari 2012. Hlm 97.

21 Sutrisno Hadi, Motodologi Research, Yogyakarta : Andi Offset, 1989, hlm. 9

22 Muh. Nadzir, Metode Penelitian, Jakarta : Ghalia Indonesia, 1996, hlm. 62.

23 Sumadi Suryabrata, Metodologi Penelitian, Jakarta : Raja Grafindo Persada, 1995, hlm. 16.

24 Hadari Nawawi, Metodologi Penelitian Bidang Sosial, Yogyakarta : Gajah Mada Press, 1995, hlm. 80

25 Hadari Nawawi, Metodologi Penelitian Bidang Sosial, Yogyakarta : Gajah Mada Press, 1995, hlm. 80

26 John W. Best, Research in Education, dalam Sanapiah Faisal dan Mulyadi Guntur Warseso (Peny.), Metodologi 
penulis gunakan untuk menginterpretasikan kondisi dan pendidikan pesantren dan selanjutnya akan mengarah pada nilai-nilai deradikalisasi agama dalam kurikulum pesantren.

\section{E. Temuan Penelitian dan Pembahasan}

\section{Deradikalisasi Agama dalam Pemaknaan Jihad}

Secara leksikal, jihad diartikan sebagai "upaya keras", "perjuangan mati-matian", atau dalam bahasa Jawa disebut usaha "pol-polan" untuk melawan sesuatu yang salah. Sedangkan jihad secara terminologis, menurut Mustofa Al-Khin, adalah "mencurahkan kemampuan untuk menegakkan agama, menjunjung tinggi kalimat Allah, dan membumikan syari'at-Nya". Sementara menurut Wahbah Zuhaili, jihad merupakan "upaya pencurahan tenaga secara fisik yang diproyeksikan untuk mengimplementasikan pesan-pesan Tuhan di muka bumi guna mengaktualisasikan tugas-tugas manusia sebagai khalifah-Nya. ${ }^{27}$

Berdasarkan defenisi di atas, maka jihad dalam istilah syariat ${ }^{28}$ dapat dimaknai sebagai perjuangan (bukan hanya peperangan) untuk menegakan kebenaran dalam menjunjung tinggi agama Islam. Jadi apapun bentuknya, perjuangan yang dilandasi dengan tujuan untuk menegakan kebenaran agama, itu dinamakan jihad. Namun pengaplikasiannya tentu harus melalui prosedur dan fase-fase yang sudah digariskan oleh syariat. Artinya, dalam tataran praktis, syariat telah menentukan bentuk-bentuk jihad dalam berbagai medan perjuangan. Tidak semua tindakan dapat dikatakan sebagai jihad jika tidak memenuhi prosedur atau kriteria yang telah ditentukan syariat. Perang melawan orang kafir dengan mengangkat senjata, misalnya, hanya merupakan salah satu (dan bukan satu-satunya) media untuk berjihad. Dan kitab-kitab fiqh di sejumlah pesantren banyak sekali yang membahas khusus tentang masalah ini.

Dalam literatur-literatur Pesantren, istilah "jihad" memiliki cakupan makna yang sangat komprehensif; pertama, mujahadah, yaitu perang spiritual melawan hawa nafsu; ${ }^{29}$ kedua, ijtihad, yaitu mencurahkan kemampuan guna mencetuskan hukum (Islam) melalui metode yang ketat, dan diproyeksikan untuk mencetuskan pendapat independen dalam yurisprudensi Islam dengan metode analogi (qiyas) melalui fondasi ratio-legis (ilat) yang terpetik dari AlQur'an dan Hadits; ${ }^{30}$ ketiga, qital fi sabil Allah, perang untuk membela agama dari sesuatu yang mengancamnya dengan kode etik yang telah dijelaskan al-Quran dan Hadits. ${ }^{31}$

Mujahadah adalah fase yang paling berat. Perjuangan mujahadah di samping bersifat

Penelitian Pendidikkan, Surabaya : Usaha Nasioanl, 1982, hlm. 119.

27 Wahbah al-Zuhaili, al-Fikh al-Islami wa Adillatuh, Beirut : Darul Fikr, 1997, jilid 8, hlm 5846.

28 Dalam konsep ushul fiqh disebutkan, bahwa bila kita menemukan kalimat yang umum digunakan dalam syariat, maka definisinya harus mengikuti terminologi syariat. Jika belum ada definisi dari syariat, maka pengertian tersebut diserahkan pada pendapat publik ( urf al-nas), karena secara dhahir syariat telah memberikan justifikasi hukum terhadap apa yang mereka ketahui. Setelah itu, barulah kemudian didefinisikan secara lughat (etimologi), itupun bila publik tidak mampu menjawabnya. Lihat Badruddin Bin Muhammad Bahadir al-Zarkasyi, Bahr alMuhith, Beirut: Dar al-Kutub, t.t. jilid 5, hlm. 87.

29 Ibrahim al-Bajuri, al-Bajuri, Indonesia: Maktabah Dahlan, t.t, Jilid 2, hlm. 261.

30 Al-Ghazali, al-Mustasfa, Beirut: Darul Kutub al-Ilmiah, 2000, hlm 342.

31 Wahbah al-Zuhaili, al-Fikh al-Islami wa Adillatuh, Beirut : Darul Fikr, 1997, jilid 8, hlm 5846. 
individual dalam menghadapi hawa nafsu, juga limit perjuangan itu bersifat kontinue sepanjang masa. Diceritakan, ketika Rasulullah SAW. kembali pulang dari Perang Badar, para sahabat banyak yang bangga dengan kemenangan yang telah mereka raih, karena dengan jumlah yang sedikit, mereka mampu mengalahkan musuh yang jumlahnya berlipat ganda. Tetapi Rasulullah SAW. mengingatkan para sahabat:

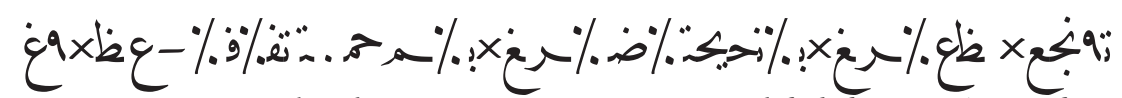

Artinya: "Kita kembali dari peperangan yang kecil menuju peperangan yang lebih besar. "(HR. Ibnu Majah). ${ }^{32}$

Peperangan yang lebih besar yang dimaksud Rasul SAW. dalam hadits di atas tidak lain adalah peperangan melawan hawa nafsu (mujahadah). Inilah jihad yang paling besar dan berat dalam pandangan Islam.

\section{Aplikasi Deradikalisasi Agama tentang Jihad di Pesantren}

Dalam masalah jihad, pesantren lebih memprioritaskan diri pada jihad di dunia pendidikan, karena pendidikan dianggap lebih efektif dan menjanjikan dalam mempersiapkan generasi masa depan dalam menyebarkan agama Islam. Terbukti, sejak zaman penjajahan sampai sekarang, kiprah pesantren sangat besar dalam sejarah pendidikan di Indonesia. Banyak alumni-alumni pesantren yang telah berhasil menyebarluaskan ajaran Islam melalui pendidikan, disamping juga berhasil mempertahankan eksistensi akidah Islam dari rongrongan para misionaris salib. Pesantren lebih condong terhadap pendidikan karena berpegang pada firman Allah yang berbunyi:

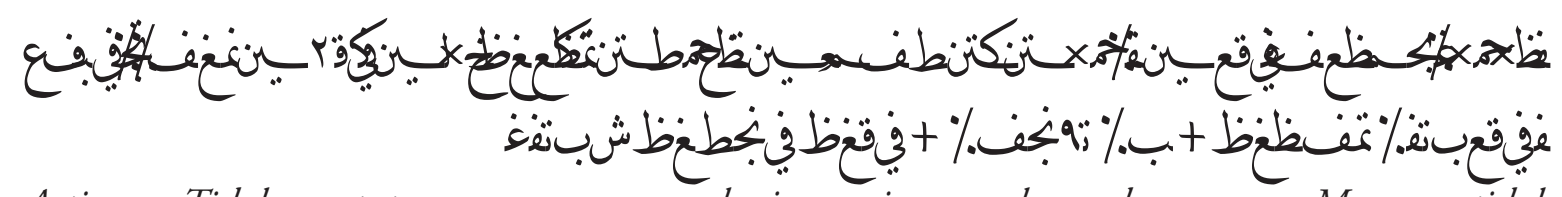

Artinya: Tidak sepatutnya orang-orang mukmin pergi semua ke medan perang. Mengapa tidak pergi dari tiap-tiap golongan diantara mereka beberapa orang untuk memperdalam pengetahuan agama dan untuk memberi pengetahuan kepada kaum mereka, bila kelak mereka telah kembali kepada kaumnya, supaya mereka dapat memelihara diri. ${ }^{33}$ (QS. atTaubat: 122)

Dan firman Allah:

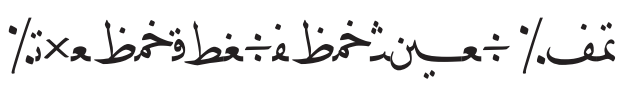

Artinya: Peliharalah dirimu dan keluargamu dari api neraka. (QS. at-Tahrim: 5$)^{34}$

Serta kaidah fiqh:

32 Jamaluddin al-Suyuthi, "Syarh Sunan Ibnu Majah", editor: Abdul Ghani dan Fakhr al-Hasan al-Dahlawi, Karachi: Qadim Kutub Khanah, jilid 1, hlm 282, Maktabah Alfiyah li al-Sunnah al-Nabawiyah 1999.

33 H.A. Sunarjo, al-Qur'an dan Terjemahannya, Jakarta: Yayasan Penyelenggara Penterjemah/Pentafsir AlQur'an, t.t. hlm 302.

34 H.A. Sunarjo, al-Qur'an dan Terjemahannya, Jakarta: Yayasan Penyelenggara Penterjemah/Pentafsir AlQur'an, t.t. hlm 191. 


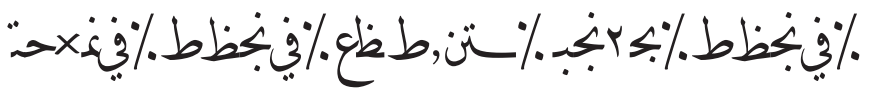

Artinya: Perbuatan yang manfaatnya bersifat umum lebih baik daripada perbuatan yang manfaatnya terbatas. ${ }^{35}$

Pesantren memandang bahwa jihad dengan pendidikan lebih efektif dan efisien dibandingkan jihad dengan cara lain. Wali Songo mampu menyebarkan Islam hampir di seluruh tanah Jawa, dengan memilih jihad di jalur pendidikan. Sekali lagi, jihad tidaklah identik dengan perang, jihad merupakan suatu proses untuk menegakkan kalimat tuhan, sehingga jihad mempunyai beberapa cakupan makna. Perang merupakan salah satu bentuk realisasi jihad dengan menggunakan kekerasan dan pedang, sedangkan pendidikan mensyiarkan agama tuhan dengan kebijaksanaan dan kasih sayang, Namun keduanya mempunyai tujuan yang sama, yaitu sama-sama menegakkan agama Allah ${ }^{36}$. Dalam hal pendidikan, Abi Darda' mengatakan "Barang siapa berpendapat bahwa pendidikan bukan jihad, maka sungguh pendapat dan akalnya tidak sempurna ${ }^{37}$.

\section{Deradikalisasi Agama dalam Pemahaman Amar Ma'ruf}

Hadits yang biasa dijadikan rujukan dalam amar ma'ruf adalah hadis yang disampaikan oleh Nabi SAW. Beliau bersabda:

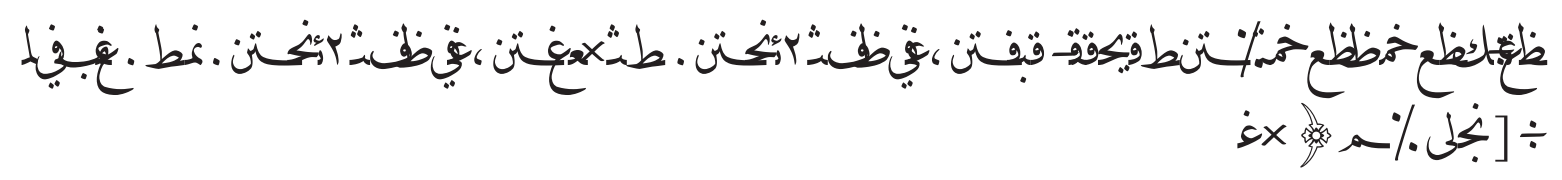

Artinya: Barang siapa di antara kalian melihat kemunkaran, maka rubahlah dengan tangannya. Jika tidak mampu maka dengan lisannya, dan jika tidak mampu maka (cukup) dengan hatinya; yang demikian itu adalah selemah-lemahnya iman. (HR. Muslim) ${ }^{38}$

Jika ditilik secara tekstual, hadits ini terkesan mengesahkan (bahkan menganjurkan) caracara kekerasan dalam ber-amar ma'ruf-nahy munkar. Padahal tidak demikian. Penyebutan kata "tangan" (kekuasaan) dalam hadits di atas, hanya menjelaskan tentang kewajiban maksimal dalam melakukan amar máruf. Artinya, jika kita seorang presiden, misalnya, maka kita dianjurkan menggunakan kekuasaan kita (dalam hadits di atas dibahasakan dengan "tangan") untuk ber-amar máruf-nahy munkar. Tapi bila kita tidak mempunyai kekuasaan, maka kita bisa menggunakan lisan saja. Dalam konteks kekinian, "lisan" itu bisa dimaknai dengan -misalnyasurat, sms, email, artikel, atau pemberitaan melalui mass media baik cetak maupun elektronik. Dan bila itupun tidak mampu, karena kita tidak punya apa-apa misalnya, maka kita harus ingkar dalam hati; tidak setuju dengan kemungkaran yang terjadi. Inilah fase paling minimal dalam ber-amar máruf-nahi munkar. Dari sini dapat ditarik benang merah, bahwa hadits di

35 al-Zarkasyi, al-Mantsur, Beirut: Dar al-Kutub al-Ilmiah, 2000, jilid 2, hlm 137.

36 Al-Ghazali, al-Mustasfa, Beirut: Darul Kutub al-Ilmiah, 2000, jilid 1, hlm 6.

37 Al-Ghazali, al-Mustasfa, Beirut: Darul Kutub al-Ilmiah, 2000, jilid 1 hlm 10.

38 Muslim bin Hajjaj al-Qusyairi al-Naisaburi, "Shahih Muslim", Beirut: Darul Ihya' at-Turats al-Arabi, jilid 1, hlm 69, Maktabah Alfiyah li al-Sunnah al-Nabawiyah 1999. 
atas (hanya) menjelaskan fase-fase kemampuan minimal dan maksimal seseorang dalam beramar ma'ruf-nahy munkar, bukan menerangkan tentang anjuran untuk mendahulukan cara-cara kekerasan. ${ }^{39}$

Sebab Dalam literatur-literatur klasik ditegaskan, bahwa pengaplikasian amar máruf-nahy munkar harus dilakukan sesuai dengan tahapan-tahapan tertentu, sehingga arahnya sesuai dengan objek dakwah masing-masing. Kita tidak dibolehkan menggunakan cara-cara kekerasan selama masih mungkin menggunakan cara-cara yang halus. Sebab kekerasan hanya dilegalkan bila keadaan sudah sangat darurat.

\section{Aplikasi Amar Ma'ruf dalam Literatur Pesantren}

Dalam literatur-literatur klasik ditegaskan, bahwa pengaplikasian amar ma'ruf-nahy munkar harus dilakukan sesuai dengan tahapan-tahapan tertentu, sehingga arahnya sesuai dengan objek dakwah masing-masing. Kita tidak dibolehkan menggunakan cara-cara kekerasan selama masih mungkin menggunakan cara-cara yang halus. Sebab kekerasan hanya dilegalkan bila keadaan sudah sangat darurat.

Dalam I'anah al-Thalibin, Al-Dimyathi menawarkan tahapan-tahapan atau fase-fase dalam ber-amar máruf sebagai berikut; (1) memberitahu, (2) menasehati, (3) mengkritik, (4) melakukan shock therapy, (5) mengancam secara lisan, (6) mengancam secara fisik, dan (7) mengangkat senjata. ${ }^{40}$

\section{1) Memberitahu}

Orang yang melakukan kemunkaran terkadang tidak menyadari bahwa perbuatannya adalah kemunkaran, atau dia menyadarinya tapi saat itu dia sedang lalai sehingga perlu diberitahu. Contohnya adalah orang yang main-main dalam salatnya. Cara memberitahu harus dengan bahasa yang halus dan sikap yang santun, karena setiap orang pasti tidak suka dikata-katain kasar. Hal ini untuk mengantisipasi agar dia tidak sakit hati, dan agar dia merasa dihargai dan tidak dianggap sebagai orang yang bodoh. Tidak dianggap berakal orang yang membasuh darah dengan darah, atau membasuh darah dengan air kencing. Orang yang mengingatkan orang lain dengan cara kasar, sama saja dengan membasuh darah dengan darah. ${ }^{41}$

\section{2) Menasehati}

Memberikan nasehat atau mengingatkan para pelaku kemungkaran mengenai ancaman Allah Swt. di akhirat kelak. Hal itu merupakan kewajiban bagi setiap Muslim. Contohnya seperti orang yang terbiasa mabuk-mabukan; sangat dianjurkan bagi kita agar memberi peringatan sekaligus memberitahu akan dampak negatif dari perbuatannya. Namun sekali lagi, semua itu harus dilakukan dengan bahasa yang halus dan sikap yang santun. Usahakan agar kita tidak seperti menggurui, melainkan mengajaknya berfikir akan malapetaka yang mungkin timbul

39 Abu Zakaria Yahya bin Syaraf al-Nawawi, "Syarh al-Nawawi 'ala Shahih Muslim”, Beirut: Darul Ihya' at-Turats al-Arabi, jilid 2, hlm 25, Maktabah Alfiyah li al-Sunnah al-Nabawiyah 1999.

40 Lihat antara lain; Ibnu Muhamad Syatha al-Dimyathi, I'anab al-Thalibin, Beirut: Darul Fikr, t.t. jilid 4, hlm 172.

41 Ibnu Muhamad Syatha al-Dimyathi, I'anab al-Thalibin, Beirut: Darul Fikr, t.t. jilid 4, hlm 325. 
akibat perbuatannya. Aplikasi jihad dengan menggunakan nasehat ini didasarkan pada firman Allah Swt.:

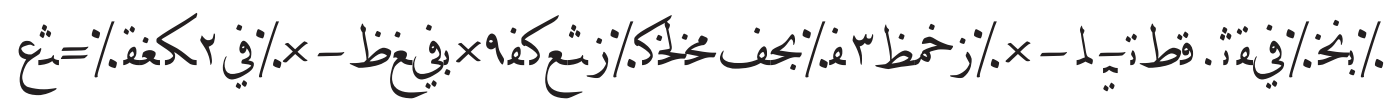

Artinya: Serulah (manusia) kepada jalan Tuhanmu dengan hikmah dan pelajaran yang baik, dan berbantahlah dengan mereka melalui cara yang lebih baik. (QS. Al-Nahl: 125)42

Dari ayat ini jelas bahwa cara halus merupakan hal yang paling diutamakan dalam Islam. Orang lain akan lebih simpati dan tertarik bila ia merasa dihargai. Bahkan ia akan cenderung mengikuti ajakan kita ketika apa yang kita sampaikan merupakan sebuah kebenaran dan dapat diterima akal. Untuk mencapai semua itu, maka perlu cara-cara yang halus dalam berdakwah, baik itu melalui perang wacana, adu argument, dan diskusi. Hal ini akan lebih efektif dan efisien daripada perang urat saraf.

Dalam tahap ini, yang harus kita hindari adalah memandang rendah orang lain dan menganggap tinggi diri kita sendiri, serta jangan membeda-bedakan perlakuan terhadap orang pintar dan orang bodoh. Ini seringkali kita lalaikan dalam ber-amar máruf sehingga kita tidak mendapatkan hasil yang maksimal. Bila ini kita lalaikan, maka amar máruf yang kita lakukan tidak lebih baik daripada kemungkaran yang kita hadapinya. Kita bagaikan orang yang menyelamatkan orang lain dari kobaran api, sementara diri kita sendiri terbakar di dalamnya.

Karena itu, sebelum memberi nasehat terhadap orang lain, sebaiknya kita lebih dahulu menasehati diri kita sendiri. Buang jauh-jauh rasa bangga diri, karena itu adalah penyakit hati yang akan menggerogoti amal kita sendiri. Dikisahkan, suatu hari Daud at-Tha'i dimintai pendapat tentang seorang laki-laki yang menolak menjadi pegawai pemerintahan. Daud ditanyai apakah laki-laki tersebut takut dicambuk? "Dia tidak takut dicambuk," Jawab Daud. ”Lalu apakah dia takut dilukai?" tanya lelaki itu lagi. "Dia tidak takut dilukai. Dia takut terhadap penyakit hati, yaitu bangga pada diri sendiri $(u j u b) . " 43$

\section{3) Mengkritik}

Tahap ketiga ini berlaku ketika kita sudah tidak mampu lagi menghentikan kemunkaran dengan menggunakan dua metode sebelumnya, bahkan terdapat indikasi adanya pengingkaran dan penghinaan dari si pelaku. Namun perlu diingat, kritik yang kita sampaikan janganlah terlalu kasar dan jangan mengandung unsur penghinaan yang bersifat fisik maupun psikis, apalagi mengandung unsur kebohongan dan penipuan. Usahakan kritik kita bersifat jujur, logis, lugas, tegas, serta konstrukstif-membangun. ${ }^{44}$

Bila terdapat indikasi bahwa kritik yang kita sampaikan tidak memberi efek positif sedikitpun, maka sebaiknya kita diam saja. Jangan keburu marah atau berkata-kata kasar. Walaupun demikian, kita wajib memperlihatkan bahwa diri kita ingkar terhadap kemungkaran

42 Muhammad bin Jarir al-Thabari, Op. Cit, jilid 14, hlm. 199, Maktabah Alfiyah li al-Sunnah alNabawiyah 1999.

43 Al-Ghazali, al-Mustasfa, Beirut: Darul Kutub al-Ilmiah, 2000,, jilid 2, hlm 325.

44 Al-Ghazali, al-Mustasfa, Beirut: Darul Kutub al-Ilmiah, 2000, jilid 2, hlm 325. 
yang dilakukannya.

\section{4) Melakukan Shock Therapy}

Shock therapy yang dimaksud di sini adalah melakukan aksi pengrusakan alat-alat yang biasa digunakan untuk berbuat kemungkaran, seperti memecahkan botol bir, atau merusak alatalat judi. ${ }^{45}$ Namun perlu diingat, pengrusakan ini jangan sampai mengarah pada pengrusakan rumah-rumah atau mencederai secara fisik. Pengrusakan ini hanya diarahkan pada alat-alat kemungkaran saja, sebagai shock therapyagar kemungkaran tersebut tidak dilakukan lagi.

Dalam tahap ini terdapat dua hal yang harus dicatat; pertama, tidak langsung bertindak keras selama masih mampu menangani dengan cara yang halus; $k$ edua, dilakukan secara efektif dan efisien. ${ }^{46}$ Artinya, pilih dan pilah dulu apa saja alat-alat yang akan kita rusak serta bagaimana cara merusaknya, baru setelah itu kita bertindak. Seleksi seperti ini sangat dibutuhkan agar tindakan kita lebih efektif dan efisien. Ambil contoh; ketika kita hendak men-sweeping warung remang-remang, misalnya, kita jangan langsung membakar warungnya meskipun di sana jelas-jelas terdapat kemungkaran, melainkan kita ambil botol-botol minuman keras dan alatalat judinya, lalu kita bawa ke lapangan dan kita bakar di sana, sementara bos pemilik warung remang-remang itu kita tangkap dan kita serahkan kepada polisi.

Kewajiban bagi kita -secara personal- adalah berupaya menghilangkan kemungkaran yang sedang terjadi, tidak lebih dari itu. Untuk tindakan selanjutnya, seperti pemberian hukuman, denda, pemenjaraan, atau pemberian balasan setimpal kepada pelaku kemungkaran, diserahkan sepenuhnya kepada pemerintah. Pemerintah boleh menggusur lokalisasi, membakar warung remang-remang, membumi-hanguskan diskotik-diskotik dan lain sebagainya, sesuai pertimbangan kemaslahatan rakyat. Syariat memandang bahwa penggusuran dan sebagainya boleh dilakukan jika memang ada kebutuhan. Bila pemerintah tidak melakukan penggusuran, padahal tempat-tempat maksiat sudah menjamur di mana-mana, maka hal itu bukanlah merupakan penganuliran hukum syariat, melainkan penangguhan atas pemberlakuan hukum tersebut di kala timbul persoalan serupa. ${ }^{47}$ Pemberian hukuman terhadap pelaku kemungkaran hanya menjadi wewenang pemerintah, karena kebijakan tersebut memang membutuhkan pertimbangan yang sulit dan rumit, sehingga rakyat tidak dibolehkan main hakim sendiri karena hal itu akan menimbulkan dampak yang lebih besar lagi.

\section{5) Mengancam Secara Lisan}

Ancaman secara lisan ditujukan untuk menakuti pelaku kemungkaran. Contohnya kita mengatakan; "Tinggalkan perbuatan itu atau kupukul pundakmu!" dan kata-kata lain yang senada. ${ }^{48}$ Jika dia masih saja melakukannya, maka kita sebaiknya mewujudkan ancaman kita agar kita tidak dipandang sebelah mata olehnya. Namun perlu diingat, kata-kata yang kita ucapkan tidak boleh berupa kalimat yang haram direalisasikan. Misalnya kita mengatakan,

45 Abu Sa'id al-Khadimi, al-Bariqah Syarh Thariqah, Istanbul: Hakikat Kitabevi, 2003. jilid 2, hlm 1068. 46 Al-Qalyubi dan Umairah, Hashiyata Qalyubi wa Umairah, Beirut: Darul Fikr, t.t. jilid 4, hlm 208. 47 Al-Ghazali, al-Mustasfa, Beirut: Darul Kutub al-Ilmiah, 2000, jilid 2, hlm 327.

48 Muhammad bin Ahmad al-Syarbini, "Mughni al-Muhtaj", jilid 5, hlm 534, Game’ Al-Fiqh Al-Islami 1999. 
“Tinggalkan perbuatan itu atau kubunuh anakmu!" Sebab membunuh orang lain adalah haram sehingga mengatakannya pun juga haram. Namun bila kita sudah terlanjur mengatakannya (tanpa sengaja), maka kita boleh merealisasikannya dalam bentuk yang lain, misalnya dengan pemukulan atau tendangan, dan ini tidak dikategorikan sebagai kebohongan karena terdapat unsur amar ma'ruf..$^{49}$

\section{6) Mengancam Secara Fisik}

Tindakan secara fisik boleh dilakukan jika keadaan memang sangat mendesak (darurat) dan hal itu dianggap efektif untuk mencegah kemunkaran, disamping tidak disertai dengan ancaman senjata. Dan ketika kemunkaran tersebut telah hilang, maka tindakan fisik tidak boleh dilakukan lagi. Namun bila suatu kemunkaran hanya bisa dihilangkan dengan menggunakan senjata, maka kita boleh menggunakannya, dengan syarat ada efek jera pada diri pelaku serta tidak menimbulkan fitnah yang lebih besar. ${ }^{50}$ Contohnya ada pelaku kejahatan menyandera seorang wanita, semenetara jarak kita dengannya dihalangi oleh sungai besar. Dalam situasi seperti ini, kita terlebih dahulu harus memberi ultimatum agar dia segera melepaskan sang sandera. Jika dia tidak mengindahkan, maka kita boleh menembak anggota badannya yang tidak mematikan (betis atau kaki, misalnya). Bila upaya ini pun gagal, bahkan ada indikasi dia akan membunuh sandera, maka kita boleh menembak anggota badan yang mematikan (perut atau dada, misalnya). Ini hukumnya dibolehkan karena kondisi memang menuntut demikian dan tidak ada cara lain yang bisa dilakukan selain membunuhnya.

\section{7) Mengangkat Senjata}

Ketika kemungkaran sudah meraja lela dan pelakunya berjumlah sangat banyak (misalnya dilakukan oleh sindikat besar), maka kita pasti tidak mampu menghilangkannya seorang diri. Kita butuh bantuan orang lain. Persoalannya, apakah perang melawan sindikat ini hukumnya dibolehkan? Apakah ini tidak melancangi kewenangan pemerintah (dalam hal ini, aparat kepolisian)? Ulama terpilah dalam dua pendapat. Pendapat pertama menyatakan, rakyat tidak boleh melakukan tindakan sendiri karena akan menimbulkan mafsadah yang lebih besar, yakni akan mengakibatkan timbulnya kerusakan, ketakutan, keresahan, jatuhnya korban jiwa, dan berakibat runtuhnya tatanan kehidupan yang normal, kecuali jika mendapat izin pemerintah. Sementara pendapat kedua membolehkannya dan tidak butuh izin dari pemerintah, karena secara analogis, rakyat yang melakukan amar máruf pasti telah melakukannya fase demi fase hingga kemudian sampai pada fase tertinggi (peperangan). Karena itu, masih menurut pendapat kedua ini, inisiatif rakyat untuk menyerang itu dibolehkan karena sudah sesuai prosedur syar'i. ${ }^{51}$

Menurut hemat penulis, pendapat pertama (yang melarang penyerangan) lebih unggul karena dalil naqli-nya lebih kuat (dar' al-mafasid muqaddam 'ala jalb al-mashalih, la dharar wa la dhirar, dll.) dan sesuai dengan pertimbangan kemaslahatan universal (al-mashalih alammah) yang merupakan tujuan utama pemberlakuan syariat Islam (al-maqashid al-syar'iyyah). Disamping itu, pendapat pertama lebih realistis karena sesuai dengan realitas empirik di 
lapangan. Berbeda dengan pendapat kedua yang cenderung idealistik dan hanya mendasarkan pendapatnya pada azas hukum logika dan analogi, sehingga argumen mereka tampak rapuh secara naqli dan tentunya non-empiris.

\section{Deradikalisasi Agama dalam Prosedur Menggunakan Kekerasan}

Ajaran Islam yang membawa misi menebar kemaslahatan universal, tentu tidak akan "nyaman" melihat ketidakadilan merajalela di muka bumi. Ketimpangan sosial merebak, yang kuat menindas yang lemah, yang kaya menghancurkan yang miskin, hak azasi ditindas, harga diri dicampakkan, dan nyawa dibuang dalam tong-tong sampah sejarah. Ajaran Islam yang menunjung tinggi persamaan derajat, menawarkan konsep jihad dengan peperangan untuk melawan beragam bentuk ketidakadilan, atau menumpas para pembuat teror, provokator, pemberontak, pengobar anarkhisme, dan lain sebagainya. Jihad dengan peperangan diciptakan tidak lain adalah untuk memberantas ketimpangan semacam ini, karena Islam datang dengan maksud untuk memberi pencerahan, pembebasan, dan melawan penindasan. ${ }^{52}$ Allah Swt. berfirman:

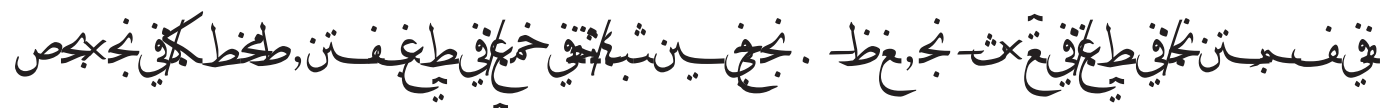

Artinya: Seandainya Allah tidak menolak゙(keganasan) sebagian manusia dengan sebagian yang lain, pastilah bumi ini akan rusak. Tetapi Allah mempunyai karunia baik (yang dicurahkan) atas semesta alam. (QS.al-Baqarah:251) $)^{53}$

Ketika pertama kali datang, Islam langsung dihadapkan dengan kebobrokan zaman Jahiliyah, seperti maraknya penindasan, kebiasaan mengubur anak perempuan hidup-hidup, merebaknya judi, dan berbagai jenis kemaksiatan lainnya. Di era yang amoral ini, Islam datang dengan membawa misi pencerahan, sebagai gerakan kembali pada ajaran tauhid Nabi Ibrahim, sekaligus sebagai refleksi atas berakhirnya zaman ketidakadilan itu. Hal ini diimplementasikan dengan dakwah Nabi secara persuasive dengan mengajak masyarakat untuk berpegang teguh pada ajaran tauhid, beriman pada Satu Pencipta, dan memberikan pemahaman bahwa berhala yang selama ini mereka sembah sama sekali tidak memberikan manfaat sedikitpun, juga tidak bisa mendatangkan malapetaka. Nabi sendiri oleh Allah dibekali berbagai macam mujizat sebagai bukti akan kebenaran ajaran yang dibawanya. ${ }^{54}$

Penduduk Arab era Jahiliyah sangat berpegang teguh terhadap keyakinan nenek moyang mereka. Ajaran animisme dan dinamisme masih sangat kental dalam tradisi mereka. Sehingga ketika Nabi menyampaikan misinya, sebagian dari mereka amat keras menentang dan tidak menerima ajaran Islam. Mereka selalu menertawakan, menghina, bahkan menyakiti Nabi dan umat Islam, namun Nabi dengan kebijaksanaannya selalu bersabar dan memaafkan mereka.

Namun semakin lama kekejaman mereka semakin merajalela, sehingga limit kesabaran umat Islam mulai menipis. Jika kesewenang-wenangan dibiarkan, maka hal itu dianggap

52 Ali Ahmad Al Jurjawi, Hikmah al-Tasyri' wa Falsafatuhu, Lebanon : Dar al-Fikr, 1997. hlm 218.

53 H.A.Sunarjo, Op. Cit, h. 62.

54 Husain Afandi, Hushun al-Hamidiyyah, Surabaya: Maktabah al-Hidayah, t.t, hlm 75. 
sebagai kebodohan atau ketakutan, padahal umat Islam bukan umat pengecut. Oleh karena itu, Allah memerintahkan umat Islam untuk mengangkat senjata (berjihad), sebagai balance atas kekejaman mereka selama ini. Tak heran jika setiap peperangan yang dilakukan Nabi SAW. dan kaum Muslimin, selalu dipicu oleh tindakan musuh yang terlebih dahulu menindas umat Islam. Sebagaimana perang Khandak, perang melawan Bani Mustaliq, atau penghianatan terhadap perjanjian yang memicu pecahnya perang Badar. ${ }^{55}$ Selain itu, Nabi SAW. juga tidak pernah menghunuskan pedang atau memoncongkan panah kecuali setelah ada perintah dari Allah Swt. Allah berfirman:

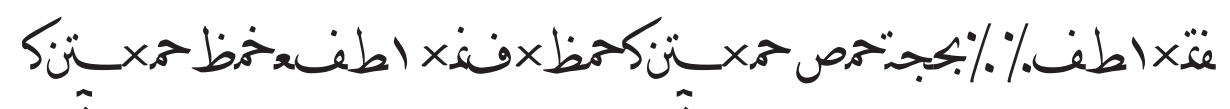

Artinya: Dan peranglah $\ddot{k} a u m$ musyrikin itu semuanya sebagaimana mereka pun memerangi kamu semuanya. (QS.at-Taubah: 36).

Dalam ayat ini, Allah Swt. secara ekplisit menyatakan bahwa perintah memerangi kaum kafir adalah karena umat Islam terlebih dahulu diperangi, bukan tanpa sebab sama sekali. Selain itu, masih banyak lagi ayat-ayat lain yang menjelaskan tentang kewajiban untuk melakukan perlawanan terhadap orang kafir yang mengintimidasi umat Islam. Hal ini menjadi bukti bahwa kewajiban jihad dilakukan ketika ada intimidasi terhadap ketentraman dan ketenangan umat Islam. ${ }^{56}$

Dalam perkembangan selanjutnya, Islam memilah kategori orang kafir dalam dua klasifikasi umum; yakni kafir harby (non-Muslim yang boleh diperangi), dan kafir dzimmy (non-Muslim yang tidak boleh diperangi karena terikat perjanjian dengan kaum Muslim). Untuk memerangi kafir harby terdapat syarat-syarat sebagai berikut:

a. Tidak terjalin perjanjian damai antara mereka dengan umat Islam. Jika terdapat perjanjian genjatan senjata atau perdamaian dengan mereka, maka umat Islam tidak boleh menghianati dan memerangi dengan alasan apapun.

b. Adanya pemberitahuan atau dakwah Islam sebelum pecahnya peperangan. Ini merupakan kode etik dakwah Islamiyah. Artinya, perang adalah pilihan terakhir, dan sebelum itu hendaknya terlebih dahulu dijalin pemahaman dan penjelasan tentang Islam. Upayakan agar mereka bisa mendapat petunjuk Allah dan masuk Islam tanpa pertumpahan darah. ${ }^{57}$

Tapi bila kedua syarat di atas telah dilakukan (oleh pemerintahan Islam), dan dijawab dengan penolakan, maka menginvasi mereka dibolehkan, dengan catatan ada maslahat yang lebih besar untuk pengembangan agama Islam. ${ }^{58}$ Salah satu bukti kemaslahatan itu terlihat dari dakwah Nabi Muhammad SAW. yang hanya berlangsung sekitar dua puluh tiga tahun. Dalam rentang waktu yang hanya sebentar itu, Nabi SAW. mampu menyulap seluruh Jazirah Arab

55 Abi Hasan Ali Bin Ahmad an-Naisaburi, Asbab al-Nuzul, Beirut : Darul Fikr, t.t. hlm 163.

56 Syekh Ali Ahmad al-Jurjawi, Hikmah al-Tasyri' wa Falsafatuhu, Lebanon : Dar al-Fikr, 1997, Hlm 220

$57 \mathrm{Hal}$ ini terpotret dari upaya Nabi SAW. yang terlebih dahulu mengirimkan surat yang berisi tawaran untuk masuk Islam kepada beberapa Raja yang menguasai wilayah-wilayah di sekitar Jazirah Arabiyah, sebelum dilakukan penyerangan.

58 Musthafa Dibb al-Bugha dan Musthafa al-Khin, Figh Manhaji, Damaskus: Dar al-Qalam, 2000. hlm 485 
dan sekitarnya menjadi kawasan Islami yang telah meninggalkan berbagai tradisi hitam abad Jahiliyah.

\section{Tujuan Jihad dengan Kekerasan}

Tujuan utama jihad dengan menggunakan kekerasan, menurut al-Zarkasy, adalah untuk menyampaikan risalah yang dibawa Nabi SAW. dan memberi pencerahan kepada seluruh makhluk di muka bumi. Al-Zarkasy juga menyatakan bahwa jihad merupakan sebuah kewajiban yang bersifat mediasi (wasilah), bukan tujuan utama (maqasid), sehingga jihad dapat diwujudkan dengan cara-cara yang halus dan tanpa kekerasan, seperti dengan pendidikan, diskusi, dan memberikan pemahaman tentang agama. Pendapat al-Zarkasy ini berbeda dengan pendapat sebagian ulama yang menyatakan bahwa jihad merupakan tujuan sesungguhnya dalam upaya untuk memperoleh hidayah Allah. Menurut mereka, cara-cara halus dalam berjihad sangat sulit memberi pengaruh tanpa disertai dengan perang. ${ }^{59}$

Senada dengan pendapat Imam Zarkasy, Syekh Ali Ahmad mengatakan bahwa tujuan jihad adalah untuk membebaskan manusia dari penindasan, penganiayaan, menciptakan ketentraman, dan menghapus penjajahan. Menurut Ali Ahmad, tujuan-tujuan tersebut di atas merupakan hukum alam (sunnatuLlah) sejak Allah menciptakan makhluk-Nya. Setiap makhluk pasti akan membela diri ketika dia ditindas. Apalagi manusia diberi kelebihan akal, sehingga ia akan melawan ketika harga diri, harta, agama, atau negaranya diinjak-injak. Dengan demikian, jihad merupakan suatu kebutuhan ketika ia diartikan sebagai upaya untuk membebaskan diri dari berbagai bentuk penindasan. ${ }^{60}$

Persoalannya, jika peperangan sudah tak dapat terelakkan lagi dan menjadi satu-satunya pilihan, maka syariat memberi tiga opsi untuk dilakukan oleh Kaum Muslimin; pertama, menunjukkan kepada kaum Kafir ke jalan yang benar. Ini adalah ending yang paling mulia; kedua, berupaya mati syahid dengan cara-cara yang benar. Ini adalah ending kedua; dan ketiga, membunuh orang kafir yang berupaya menyerang kita. Ending terakhir ini bukanlah tujuan utama dari jihad, karena harus menelan korban jiwa orang (kafir) yang masih mungkin menjadi orang beriman, atau setidak-tidaknya melahirkan keturunan yang nantinya akan berjuang di jalan Allah. ${ }^{61}$

Dari beberapa kesimpulan di atas, dapat dijelaskan bahwa berperang melawan orang kafir bukanlah tujuan pokok dari jihad. Jihad dengan mengangkat senjata hanya merupakan media untuk menggapai pembebasan dan pencerahan. Terbukti, ketika misi tersebut bisa dicapai dengan melakukan gerakan persuasif, maka perang tidak lagi dilegalkan, karena tujuan utama jihad adalah pembebasan dari ketidakadilan, penindasan, dan berbagai ketimpangan sosial lainnya.

Langkah-langkah persuasif tersebut adalah; Pertama, memberikan penjelasan secara baik dan halus tanpa kekerasan. Pahami adat istiadat dan struktur budaya masyarakat, sehingga

59 Syekh Abdul Hamid, Khawaasyis Syarwani, Lebanon: Darul Kutub al-Ilmiah, 1996, hlm 3

60 Ali Ahmad Al Jurjawi, Hikmah al-Tasyri' wa Falsafatuhu, Lebanon : Dar al-Fikr, 1997. Hlm 217.

61 Taqiyyuddin Ali al-Subki, Fatawi al-Subki, Darul Ma’arif, t.t. hlm 340 
dakwah yang kita sampaikan bisa membumi dan integral dengan kondisi masyarakat setempat. Hal ini pernah dilakukan Wali Songo ketika menyebarkan agama Islam di tanah Jawa. Mereka mampu mengislamkan sebagian besar tanah Jawa tanpa setetespun darah yang mengalir.

Kedua, melakukan peperangan saat langkah-langkah persuasif sudah tidak memberikan hasil sama sekali. Tetapi hal ini harus melalui keputusan pemerintah (Islam), bukan rakyat perseorangan atau golongan tertentu, disamping harus mempertimbangkan kekuatan dan kemampuan militer yang dimiliki kaum Muslimin.

\section{Islam Agama Kasih Sayang: Perspektif Literatur Pesantren}

Istilah rahmah adalah bentuk masdar dari fil madhi rahima. Kata ar-rahmah memiliki beberapa makna di antaranya : menaruh belas kasih, belas kasihan atau menginginkan kebaikan, menaruh simpati, iba dan mengampuninya. ${ }^{62}$ Akan tetapi dalam konteks kalimat, kata tersebut digunakan untuk menyatakan suatu pengertian saja yaitu kasih sayang atau kebajikan. Karenanya apabila ada kata ar-rahmah disandarkan kepada Allah SWT, maka kata tersebut mengandung pengertian al-ihsan, sedangkan bila disandarkan kepada manusia maka kata tersebut mengandung pengertian kasih sayang dan belas kasihan. ${ }^{63}$ Berhubung pembahasan ini menggunakan pendekatan sosiologis atau kemasyarakatan maka kata rahmah diartikan sebagai kasih sayang dan belas kasihan.

Terkait sikap kasih sayang, Nabi Muhammad SAW diutus untuk umat manusia dengan tujuan utama menebarkan kasih sayang. Sebagaimana firman Allah SWT dalam surat Al Anbiya' ayat 107:

Artinya: Dan tiadalah Kami mengutus kamu, melainkan untuk (menjadi) rahmat bagi semesta alam (Al Anbiya: 107).

Menurut Imam Thobari, ayat di atas secara jelas menyatakan bahwa Nabi Muhammad diutus Allah SWT untuk menebarkan kasih sayang bagi seluruh umat manusia, tanpa ada pengecualian, baik muslim maupun non muslim ${ }^{64}$. Berdasarkan ayat tersebut sebuah keharusan bagi setiap manusia untuk saling menyayangi satu dengan lainnya. Bahkan nabi sendiri menyatakan bahwa: ${ }^{65}$

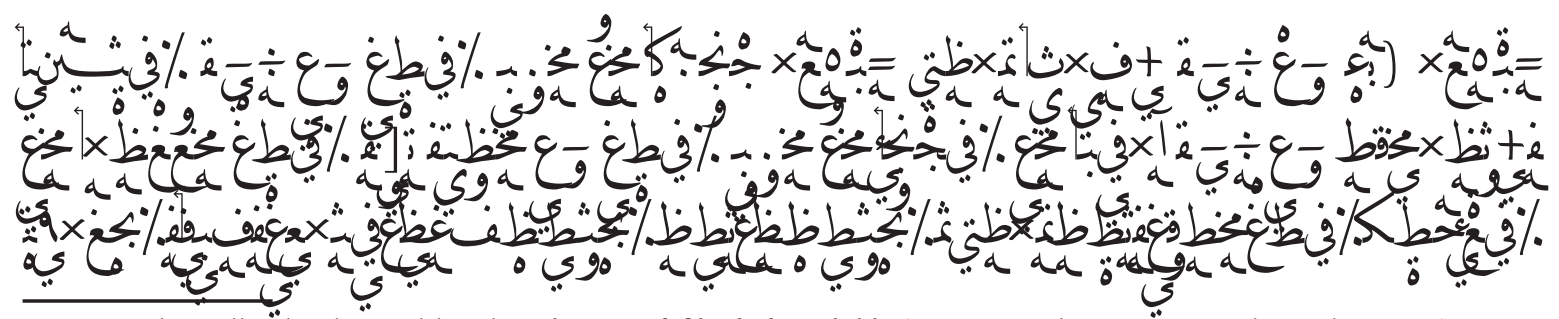

62 Al Madbaäh Al Kasulikiyah. Al-Munjid filughah walakla (Beirut - Libanon : Dar El-Machreq Sar), 1986. Hlm. 253

63 Abdul Aziz "Rahmah" dalam Hasan Muarif Ambary (et. al). Suplemen Enssiklopedi Islam, Jakarta : Ichtiar Baru Vaaan Hoeve, 1996 hlm. 117

64 Muhammad bin Jarir at-Thobari, Tafsir at Thobari, Dar Hijr: 2001, juz 16, hlm 439.

65 Imam Bukhori. Shahih Bukhori, juz 1 (Libanon, Beirut: Darul Fikr), hlm. 11. 


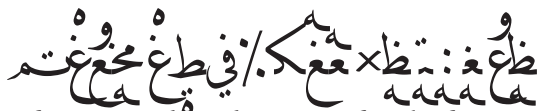

Artinya: "Seorang muslim adalah orang yang tidak melukai saudara muslim lainnya baik dengan lisan dan tangannya, orang yang hijrah adalah orang yang meninggalkan larangan Allah SWT (HR. Bukhori)".
\end{abstract}

Hadits di atas menjelaskan bahwa kehidupan masyarakat muslim harus saling menghormati, memberikan kasih sayang tidak saling mengzalimi karena hal itu adalah perbuatan yang buruk jauh dari kebenaran sehingga persaudaraan sesama muslim tidak harmonis mengakibatkan kehancuran.

Untuk memahami makna kasih sayang atau rahmah ada baiknya bila dikemukakan perikehidupan Rasulullah. Rasulullah Muhammad saw dalam kehidupan sehari-hari telah mencerminkan sikap kasih sayang (rahmah) nya terhadap anak-anak, rakyat bawahan, terhadap orang-orang tua, dengan mencintai dan menyantuni mereka. Terhadap orang-orang yang lemah ekonominya atau lemah keadaan sosialnya, beliau menunjukkan kasih sayangnya dengan membela nasib mereka dari tindakan kesewenang-wenangan serta penghisapan dengan memberikan hak-hak mereka, menegakkan dasar keadilan. Sikap kasih sayang ini tidak hanya beliau terapkan kepada kawan-kawan (kaum muslimin saja), tetapi kepada lawanpun beliau senantiasa menunjukkan sikap kasih sayangnya, bahkan diceritakan ketika nabi berdakwah kepada orang musyrik Quraisy untuk masuk ajaran Islam, mereka melempar Nabi dengan batu dan debu, bahkan nabi mendoakan mereka dengan doa:

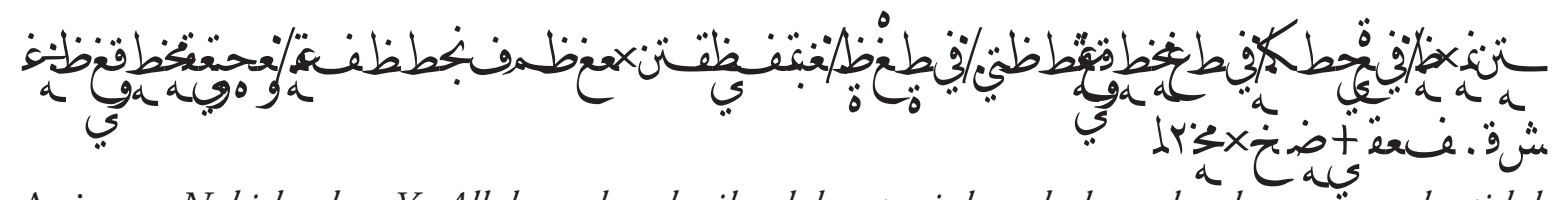

Artinya: Nabi berdoa: Ya Allah, mohon berikanlah petunjuk pada kaumku, karena"mereka tidak tahu. Mohon tolonglah aku agar mereka mau mentaatimu ${ }^{66}$

Dalam riwayat lain, Imam Bukhori meriwayatkan sebuah hadits yang menceritakan bahwa nabi pernah menceritakan sikap para nabi terdahulu, ketika mereka dilukai oleh para umatnya, nabi mendoakan: "ya Allah, ampunilah umatku, karena mereka tidak tahu”. Sebagaimana hadis berikut:

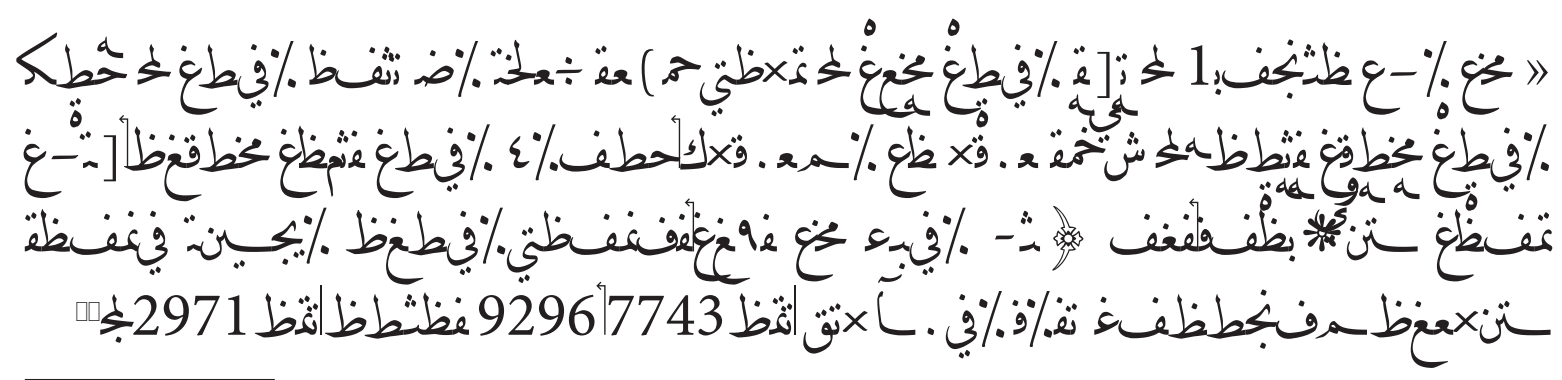

66 Imam Jalaludin Suyuthi, Durru al-Mantsur, Beirut: Dar al-Fikr, Juz 3, hlm 117.

67 Imam Bukhori, Shahih Bukhori, Damaskus: Dar Thuq Najah, Juz 4, hlm 175 
Hadits di atas menunjukkan bahwa Rasulullah Muhammad dalam membina masyarakat (umatnya) selalu menomor satukan sikap kasih sayang. Bahkan sikap terhadap musuh dilandasi dengan kasih saying, walaupum musuh melukai nabi hingga berdarah-darah, tidak segan nabi mendoakan mereka agar Allah SWT mengampuni mereka. Dengan kasih saying, nabi dapat membangun satu masyarakat marhamah yaitu kehidupan masyarakat yang diwarnai dengan semangat kasih mengasihi, cinta mencintai, tolong menolong dan harmonis ${ }^{68}$.

Dari beberapa keterangan di atas dapat disimpulkan bahwa tindakan teror yang dilakukan oleh sebagian kalangan Islam, sebenarnya berawal dari perbedaan pemahaman terhadap ajaran Islam itu sendiri. Perbedaan pemahaman tersebut terutama terkait dengan konsep jihad dan mati syahid. Karena itu, perlu dibedakan di sini antara kalangan Islam yang memahami jihad hanya dengan peperangan (mereka biasanya disebut Islam Garis Keras / Radikalis / Fundamentalis, dll), dengan kalangan Islam yang memaknai jihad itu bisa diwujudkan dalam banyak bentuk, tidak hanya perang saja, seperti kalangan Islam Moderat (termasuk pesantren).

Dalam ajaran pesantren, prinsip yang diusung adalah menyebarkan ajaran Islam yang tawasuthi wa manhaji, moderat tapi memiliki dasar kuat. Pesantren yang merupakan lahan penyemaian para ulama, mayoritas berada pada mainstream itu. Ajaran tawasut (moderat), i'tidal (tengah-tengah), tasamuh (santun), dan lain sebagainya, telah menjadi mainstream perjuangan pesantren sejak ratusan tahun yang lalu. Jadi, tuduhan bahwa pesantren merupakan sarang teroris atau penyemaian terorisme, jelas tidak bisa diterima.

\section{F. Kesimpulan}

Dalam literatur-literatur Pesantren, istilah "jihad" memiliki cakupan makna yang sangat komprehensif; pertama, mujahadah, yaitu perang spiritual melawan hawa nafsu; kedua, ijtihad, yaitu mencurahkan kemampuan guna mencetuskan hukum (Islam) melalui metode yang ketat, dan diproyeksikan untuk mencetuskan pendapat independen dalam yurisprudensi Islam dengan metode analogi (qiyas) melalui fondasi ratio-legis (ilat) yang terpetik dari Al-Qur'an dan Hadits; ketiga, qital $f i$ sabil Allah, perang untuk membela agama dari sesuatu yang mengancamnya dengan kode etik yang telah dijelaskan al-Quran dan Hadits.

Dalam masalah jihad, pesantren lebih memprioritaskan diri pada jihad di dunia pendidikan, karena pendidikan dianggap lebih efektif dan menjanjikan dalam mempersiapkan generasi masa depan dalam menyebarkan agama Islam. Terbukti, sejak zaman penjajahan sampai sekarang, kiprah pesantren sangat besar dalam sejarah pendidikan di Indonesia. Banyak alumni-alumni pesantren yang telah berhasil menyebarluaskan ajaran Islam melalui pendidikan, disamping juga berhasil mempertahankan eksistensi akidah Islam dari rongrongan para misionaris salib.

Dalam literatur-literatur klasik ditegaskan, bahwa pengaplikasian amar ma’ruf-nahy munkar harus dilakukan sesuai dengan tahapan-tahapan tertentu, sehingga arahnya sesuai dengan objek dakwah masing-masing. Tidak diperbolehkan menggunakan cara-cara kekerasan selama masih mungkin menggunakan cara-cara yang halus. Sebab kekerasan hanya dilegalkan bila keadaan

68 MA. Asyharie. Keagungan Sinar-sinar (Nur) Muhammad saw Rahmat li al-'alamin (Surabaya : Terbit Terang, 1997), hlm. 12-15. 
sudah sangat darurat. Dalam I'anah al-Thalibin, Al-Dimyathi menawarkan tahapan-tahapan atau fase-fase dalam ber-amar ma'ruf sebagai berikut; (1) memberitahu, (2) menasehati, (3) mengkritik, (4) melakukan shock therapy, (5) mengancam secara lisan, (6) mengancam secara fisik, dan (7) mengangkat senjata.

Berperang melawan orang kafir bukanlah tujuan pokok dari jihad. Jihad dengan mengangkat senjata hanya merupakan media untuk menggapai pembebasan dan pencerahan. Terbukti, ketika misi tersebut bisa dicapai dengan melakukan gerakan persuasif, maka perang tidak lagi dilegalkan, karena tujuan utama jihad adalah pembebasan dari ketidakadilan, penindasan, dan berbagai ketimpangan sosial lainnya.

Nabi Muhammad diutus Allah SWT untuk menebarkan kasih sayang bagi seluruh umat manusia, tanpa ada pengecualian, baik muslim maupun non muslim. Sebuah keharusan bagi setiap manusia untuk saling menyayangi satu dengan lainnya. Kehidupan masyarakat harus saling menghormati, memberikan kasih sayang tidak saling mendzalimi karena hal itu adalah perbuatan yang buruk jauh dari kebenaran.

Dalam ajaran pesantren, prinsip yang diusung adalah menyebarkan ajaran Islam yang tawasuthi wa manhaji, moderat tapi memiliki dasar kuat. Pesantren yang merupakan lahan penyemaian para ulama, mayoritas berada pada mainstream itu. Ajaran tawasut (moderat), itidal (tengah-tengah), tasamuh (santun), dan lain sebagainya, telah menjadi mainstream perjuangan pesantren sejak ratusan tahun yang lalu. Jadi, tuduhan bahwa pesantren merupakan sarang teroris atau penyemaian terorisme, jelas tidak bisa diterima.

\section{Bibliografi}

Afandi, Husain, Hushun al-Hamidiyyah, Surabaya : Maktabah al-Hidayah, t.t.

Asyharie. Keagungan Sinar-sinar (Nur) Muhammad saw Rahmat li al-'alamin (Surabaya : Terbit Terang, 1997).

Aziz, Abdul "Rahmah" dalam Hasan Muarif Ambary (et. al). Suplemen Enssiklopedi Islam, Jakarta : Ichtiar Baru Vaaan Hoeve, 1996

al-Bajuri, Ibrahim, al-Bajuri, Indonesia: Maktabah Dahlan, t.t, Jilid 2.

Best, John W. Research in Education, dalam Sanapiah Faisal dan Mulyadi Guntur Warseso (Peny.), Metodologi Penelitian Pendidikkan, Surabaya : Usaha Nasioanl, 1982.

Bukhori, Imam, Shahih Bukhori, juz 1 (Libanon, Beirut : Darul Fikr).

Darmadji, Ahmad, Pondok Pesantren dan Deradikalisasi Islam di Indonesia, Jurnal Millah Vol. XI, No 1, Agustus 2011. 
al-Dimyathi, Ibnu Muhamad Syatha, I'anah al-Thalibin, Beirut: Darul Fikr, t.t. jilid 4.

Al-Ghazali, al-Mustasfa, Beirut: Darul Kutub al-Ilmiah, 2000.

Hadi, Sutrisno, Motodologi Research, Yogyakarta : Andi Offset, 1989.

Hajjaj al-Qusyairi al-Naisaburi, Muslim, "Shahih Muslim", Beirut: Darul Ihya' at-Turats alArabi, jilid 1, hlm 69, Maktabah Alfiyah li al-Sunnah al-Nabawiyah 1999.

Hamid, Syekh Abdul, Khawaasyis Syarwani, Lebanon: Darul Kutub al-Ilmiah, 1996.

Hutapea, Rivai “Pesantren : Yang Berjasa Yang Tersudutkan”, Sabili,online, http:// Sabili. co .id /telut-e 13 th X111 05. htm.2004,di akses 14 Mei 2006.

Jurjawi, Ali Ahmad al, Hikmah al-Tasyri' wa Falsafatuhu, Lebanon : Dar al-Fikr, 1997.

Al-Khadimi, Abu Sa'id, al-Bariqah Syarh Thariqah, Istanbul: Hakikat Kitabevi, 2003.

Khin, Musthafa Dib al-Bugha dan Musthafa al. Fiqh Manhaji, Damaskus: Dar al-Qalam, 2000 .

Ma'arif, Nurul Huda "Pesantren (kembali) Dicurigai", AULA (Nopember 2005), hlm. 35-38.

Al Matbaah Al Kasulikiyah. Al-Munjid filughah walakla (Beirut - Libanon : Dar El-Machreq Sar), 1986.

Muhammad, Husein, 2000, “Memahami Sejarah Ahlus Sunnah wal Jama’ah yang Toleran dan Anti Ekstrem" dalam Imam Baihaqi (ed.), Kontroversi Aswaja, Yogyakarta: LKiS.

Mustofa, Imam, Pesantren dan Deradikalisasi Agama, http://mushthava.blogspot.com/2012/02/ pesantren-dan-deradikalisasi-agama.html. diunduh tanggal 11 Maret 2015.

Mustofa, Imam, Deradikalisasi Ajaran Agama: Urgensi, Problem dan Solusinya, http:// mushthava.blogspot.com/2012/02/pesantren-dan-deradikalisasi-agama.html. diunduh tanggal 11 Maret 2015.

Muzadi, Abdul Muhith, 2006, NU dalam Perspektif Sejarah dan Ajaran, Surabaya: Khalista.

Nata, Abudin, Sejarah Pertumbuhan dan Perkembangan Lembaga-lembaga Pendidikan Islam di Indonesia, Jakarta : Grasindo, 2001.

Nadzir, Muh, Metode Penelitian, Jakarta : Ghalia Indonesia, 1996.

an-Naisaburi, Abi Hasan Ali Bin Ahmad, Asbab al-Nuzul, Beirut : Darul Fikr, t.t.

al-Nawawi, Abu Zakaria Yahya bin Syaraf, "Syarh al-Nawawi 'ala Shahih Muslim”, Beirut: Darul Ihya' at-Turats al-Arabi, jilid 2, hlm 25, Maktabah Alfiyah li al-Sunnah al-Nabawiyah 1999.

Nawawi, Hadari, Metodologi Penelitian Bidang Sosial, Yogyakarta : Gajah Mada Press, 1995.

Qosim, Muhammad, Pesantren dan Wacana Radikalisme, Jurnal KARSA, Vol. IX No. 1 April 2006. 
Qulyubi dan Umairah, Hashiyata Qalyubi wa Umairah, Beirut: Darul Fikr, t.t. jilid 4.

Rahmat, Abu, Radikalisme Islam dan Upaya Deradikalisasi Paham Radikal, dalam Jurnal Walisongo, Volume 20 No. 1. Mei 2012.

al-Subki, Taqiyyuddin Ali, Fatawi al-Subki, Darul Ma’arif, t.t.

al-Suyuthi, Jamaluddin, "Syarh Sunan Ibnu Majah", editor: Abdul Ghani dan Fakhr al-Hasan al-Dahlawi, Karachi: Qadim Kutub Khanah, jilid 1, Maktabah Alfiyah li al-Sunnah al-Nabawiyah 1999.

Suyuthi, Imam Jalaludin, Durru al-Mantsur, Beirut: Dar al-Fikr, Juz 3.

Sunarjo, Ahmad, al-Qur'an dan Terjemahannya, Jakarta: Yayasan Penyelenggara Penterjemah/ Pentafsir Al-Qur'an, t.t.

Suryabrata, Sumadi, Metodologi Penelitian, Jakarta : Raja Grafindo Persada, 1995.

al-Syarbini, Muhammad bin Ahmad, "Mughni al-Muhtaj”, jilid 5, Game’ Al-Fiqh Al-Islami 1999.

Syukur, Suparman, 2012, "Islam Radikal VS Islam Rahmah Kasus Indonesia," dalam Teologia, Jurnal Ilmu-Ilmu Ushuluddin, Volume 23, Nomor 1, Januari 2012.

al-Thabari, Muhammad bin Jarir, Tafsir at Thobari, jilid 14, Maktabah Alfiyah li al-Sunnah alNabawiyah 1999.

al-Zuhaili, Wahbah, al-Fikh al-Islami wa Adillatuh, Beirut : Darul Fikr, 1997, jilid 8.

al-Zarkasyi, Badruddin Bin Muhammad Bahadir, Bahr al-Muhith, Beirut: Dar al-Kutub, t.t. jilid 5.

al-Zarkasyi, Badruddin Bin Muhammad Bahadir, al-Mantsur, Beirut: Dar al-Kutub al-Ilmiah, 2000, jilid 2. 
74 Rustam Ibrahim 